\title{
Gender and Language in Movies
}

\section{Mirjam Anugerahwati}

Dept.of English, Faculty of Letters, Universitas Negeri Malang, Indonesia

\section{Abstract}

This paper is a report on the findings of a mini research study that the writer conducted in her course Gender and Language with the students in the English Language and Literature, cohort of 2017. The students, in groups, analyzed several Disney cartoons and reported the results in PPt. The findings revealed that the cartoons contain the gender stereotypes in line with the theories.

Keywords: gender and language, stereotypes, Disney cartoons

\section{Introduction}

Corresponding Author: Mirjam Anugerahwati mirjam.anugerahwati.fs@um.ac.id

Published: 29 July 2020

Publishing services provided by Knowledge E

(c) Mirjam Anugerahwati. This article is distributed under the terms of the Creative Commons Attribution License, which permits unrestricted use and redistribution provided that the original author and source are credited.

Selection and Peer-review under the responsibility of the WCGS Conference Committee.
Gender issues have long been a topic of interest among scholars, ever since Lakoff (1975), Spender (1980) and Tannen (1990), among others, wrote their seminal articles about them. In the development, the issue of gender in language has also gained popularity (Boskovic, 2015; Oliviera, 2007; Sunderland and Swann, 2016, to name but a few). In the Department of English, Faculty of Letters, Universitas Negeri Malang, there are even three courses offered which focus on gender issues, and Gender in Language is one of them. This paper is a brief report of a small-scale research the writer has conducted with her students in the course Gender in Language in the first semester of 2019-2020. The students enrolled in this course were in the fifth semester, from the English Language and Literature (ELL) study program.

Gender and language is indeed a fertile land on which many research and studies have been conducted, be they in the contexts of movies, daily conversations, advertisements, literary works, and others. Those studies are generally included in the field of Sociolinguistics, where scholars study how men and women use language differently, and how stereotypes are then formed concerning the language usage of the two genders.

\section{Theories and Previous Studies}

Lakoff (1975) states that the ways people see women's language is influenced by S OPEN ACCESS 
She also gives characteristics of women's language, which are often cited in writings about gender and language. Some of the characteristics are that women very often use "empty adjectives" such as lovely, divine, and adorable. Women also use tag questions and hedges, which indicate uncertainty; and women are overly concerned about using correct grammar and polite forms in their speech and writings.

Dale Spender (1980) in her book "Man-made Language", proposes that differences in the way men and women speak actually causes disadvantages to women, where they are most often "silenced". In line with this thought, Tannen (1990) in her book "You Just Don't Understand", asserts that girls and boys are raised differently, and hence the different styles in speaking; women mostly speak to seek connection and intimacy, whereas men speak to show their status and independence.

Regarding the topic of this paper, i.e. gender and language in movies, several studies have come up with similar findings. Brittany (2016), for one, has listed several Disney movies that reinforce the stereotypical gender roles, which, unfortunately, sustain the view about women.

Al Zahrani (2016) investigates the portrayal of women and gender roles in the film Sex and the City, and found that women are the source of misery for men, that they are weak. They are very often objectified for men's pleasures, and they are suited for domestic jobs only.

Another study, by Murphy (2015) on the sexual objectification of women in films, reveals that even in the midst of the emergence of women leading roles in top-ranking movies such as Tomb Raider, and the Hunger Games, women are still being objectified (in terms of the amount of skin being shown), and Caucasian women more than women of color.

Li (2014) investigates the movie series "Desperate Housewives", and finds that in terms of the amount of talk and turn-taking, men still dominate; men are more talkative than women, and they have more turns in conversations than women.

However, recently UNESCO, in responding to the Sustainable Development Goals of the UN, has launched a Policy Monitoring Platform, which specifically acknowledge and promote women's contributions to cultural life, especially in addressing initiative and innovations in the film industry. This is also to support the realization of the $5^{\text {th }}$ agenda of the 2030 SDG, which is Gender Equality.

Based on those studies, the researcher wanted to find out how her students were able to analyze the gender stereotypes Disney movies/cartoons and whether this course has sensitized them to gender stereotypes. 


\section{The Task}

In one of the sessions, the writer showed some video clips of Disney movies (cartoons): the Little Mermaid, Snow White and the 7 Dwarfs, Beauty and the Beast, Aladdin, the Hunchback of Notre dame, and Hercules. The students then, in groups, were to analyze the movies in terms of the Gender theories; the Dominance, Deficit, and/or Difference theories, as well as stereotyping and bias. They had to develop PowerPoint presentations to be presented in the following meetings, and email the PowerPoint slides to the researcher.

\section{The Findings}

From the analyses of the students' PowerPoint presentations, several core findings can be revealed: that the female characters in the movies have very strong stereotypical characteristics, such as being submissive, being proud of doing house chores, and being led to believe that a woman should not be smart. Below are some of the findings that students have presented in their analyses.

From the movie "The Little Mermaid": women are valued because of their good looks and the ability to attract men through their body language. Voice is not necessary, and men even despise women who talk too much and "gossip". Therefore, Ariel should not worry about losing her voice for a pair of legs, since voice is unimportant for girls.

From" Aladdin": a woman should always obey men and accept whatever men have decided for her. Princess Jasmine is a depiction of women in general, that is, she should always stay at home, and wait for her father to marry her off to the man of his choice. However, Jasmine is actually a rebellious woman, who refuses to be married to any man whom she doesn't know, and she finally marries the man she loves. She also explicitly states that she is "not a prize to be won".

From "Snow White and the Seven Dwarfs": the way the Dwarfs look at Snow White and their words of admiration for her clearly show gender stereotypes: "cute", "pretty", "just like a princess". Another stereotype in this movie is Snow White's actions: she cooks, cleans and does all household chores very happily, and that is precisely what the dwarfs expect of her as a woman.

From the perspectives of Dominance theory, the Dwarfs are clearly dominant, in that they interrupt Snow White while she is talking, they speak in high pitch/intonation with her, and they don't really listen to what she says. 
The movie "Beauty and the Beast" shows us similar stereotypes: men are very proud of their "manliness", and women are supposed to be submissive and to adore the macho men. While most of the girls in town adore Gaston, Belle, whom he wants to marry, is totally oblivious to his good looks and charms. However, their gestures and body language still show the stereotypical things: Gaston likes to "chase" Belle and even block her way, while Belle prefers to duck and run, rather than confront him directly.

In "the Hunchback of Notre Dame", the female dancer Esmeralda gets applauded when she dances, in sexy outfit and provoking gestures. This clearly shows that women are seen mainly as seductress, and that they can easily earn money by "selling themselves".

The last movie the students analyzed is "Hercules". He is a representation of "macho men": loud, broad chested, and very proud of themselves. However, when Hercules falls in love with Meg, it is she who takes the lead in the conversation.

\section{Conclusions}

From the findings of this mini research, some conclusions can be drawn. Firstly, most of the Disney cartoons, especially the earlier ones, still present the gender stereotypes and evidences of the dominance theory.

Secondly, there are several stereotypes that the students found; that women are being dominated, but rarely do they object to it. They are happy to be housewives, to clean and cook and care for the men, and to just sing and seduce men, without doing any "serious jobs". In fact, doing household chores are seen as a way to safe themselves from the oppression and threat of men. Only Princess Jasmine objects to this situation, and finally gets what she wants.

Thirdly, women are very often objectified, and forced to abide by the rules set by men. Otherwise, she will be judged negatively by the society.

Physically, women should be slim, sweet, with beautiful voice, perfect singing skills. Men, on the other hand, are very attractive when they are well-built, with loud voice, and very strong body.

\section{Suggestions}

The mini research that the researcher did with her students in the Course Gender and Language conveys that basically the Disney movies are full of gender bias and 
stereotypes, both for women and men. However, that applies to the earlier movies. There are now movies such as Mulan, Moana, and the Brave, which show the superiority of the women characters, and try to present gender equality. Future researchers should investigate those later movies, and find out whether they really do present gender equality.

\section{References}

[1] Alzahrani, F. (2016). The portrayal of women and gender roles in films. International Journal of Science and Engineering Research vol.7, issue 4, page. 533-534.

[2] Boskovic, V. and Alcakovic, S. (2013). Gender Stereotypes and Differences in Language Usage. https://www.researchgate.net/publication/ 271134807_GENDER_STEREOTYPES_AND_GENDER_DIFFERENCES_IN_LANGUAGE_USAGE. (retrieved on Nov.8, 2019)

[3] Lakoff, R. (1973). Language and woman's place. Language and Society, vol. 2, issue 1, pp. $45-80$.

[4] Li, J. (2014). A sociolinguistic study of language and gender in "Desperate Housewives". Theory and Practice in Language Studies, vol. 4, issue 1, pp.52-57. DOI: $10.4304 /$ tpls.4.2.52-57

[5] Theodysseyonline.com. (2016, 25 April). 5 Classic Disney Movies that Unfortunately Reinforce Gender Roles. Retriever on Nov 8, 2019, from https://www. theodysseyonline.com/reinforcing-gender-roles.

[6] Murphy, J.N. (2015). The Role of Women in Film: Supporting the Men: an Analysis of How Culture Influences the Changing Discourse on Gender Representation in Films. Undergraduate thesis, University of Arkansas, Fayetteville. (retrieved on Dec.1, 2019). Theses. http://scholarworks.uark.edu (retrieved on Dec.1, 2019)

[7] Spender, D. 1980. Man-made Language. London: Routledge and Kegan Paul. www.marxists.org/reference/subject/philosophy/works/ot/spender.htm (retrieved on Nov.1, 2019)

[8] Sunderland, J. and Swann, J. (2016). Teaching Language and Gender. Lancaster University and Joan Swann, Open University. https://www.llas.ac.uk/index.html (retrieved on Nov.11, 2019)

[9] Tannen, D. (1990). You Just Don't Understand: Women and Men in Conversation. New York: Balantine Books.

[10] UNESCO. (2019). Mind the Gap: Gender Equality in the Film Industry. 